\title{
STUDY OF THE DIFFERENT WAYS OF PROTEINS EXTRACTION FROM SHEEP AND COW WHEY FOR "URDA" CHEESE PRODUCTION
}

\author{
Oksana Bilyk \\ Department of Technology of milk and milk products \\ Lviv National University of Veterinary Medicine and \\ Biotechnologies named after S. Z. Gzhytskyi \\ 50 Pekarska str., Lviv, Ukraine, 79010 \\ bilyk_oksi@ukr.net \\ Natalya Slyvka \\ Department of Technology of milk and milk products \\ Lviv National University of Veterinary Medicine and \\ Biotechnologies named after S. Z. Gzhytskyi \\ 50 Pekarska str., Lviv, Ukraine, 79010 \\ slyvkanat@ukr.net \\ Bogdan Gutyj \\ Department of Pharmacology and Toxicology \\ Lviv National University of Veterinary Medicine and \\ Biotechnologies named after S. Z. Gzhytskyi \\ 50 Pekarska str., Lviv, Ukraine, 79010 \\ bvh@ukr.net \\ Hryhoriy Dronyk \\ Department of Technology of milk and milk products \\ Lviv National University of Veterinary Medicine and \\ Biotechnologies named after S. Z. Gzhytskyi \\ 50 Pekarska str., Lviv, Ukraine, 79010 \\ bilyk_oksi@ukr.net

\section{Olha Sukhorska} \\ Department of Ecology and Biology \\ Lviv National University of Veterinary Medicine and \\ Biotechnologies named after S. Z. Gzhytskyi \\ 50 Pekarska str., Lviv, Ukraine, 79010 \\ olgaps@ukr.net
}

\footnotetext{
Abstract

The necessary stage of technological process of "Urda" albumin cheese production is whey proteins extraction from sheep whey (in classic technology of product) or from the whey mixtures, offered in the work. For whey proteins extraction from whey the following ways are used: thermal, acid, acid-alkaline and chlorine-calcium.

There was established the equal dependence of the influence of the way of proteins extraction from both sheep and cow whey on the output of protein mass.

The most output of protein mass $(3,47 \pm 0,10 \%)$ is at the chlorine-calcium way of proteins extraction, a bit less $3,41 \pm 0,08 \%$ - at the acid-alkaline way. But the acidity of such protein mass, received by the chlorine-calcium and acid-alkaline ways is not high $-37,2 \pm 1,8$ and $45,6 \pm 1,4 \%$ respectively that negatively influences the gustatory qualities of product. The least output is registered at the thermal way. Albumin cheese, received from such protein mass, was the best by its gustatory qualities. The output of protein mass from sheep whey is 1,60 times higher than from cow whey. The mass share of proteins in protein mass, received from sheep whey is by $6,9 \ldots 8,0 \%$ higher comparing with one, received from cow whey.

Protein mass, received from sheep whey by the chlorine-calcium and acid-alkaline ways has the low titrated acidity. Cheese, received from protein mass, received of sheep whey by the acid method, has the extremely high acidity values $\left(115,5 \pm 1,5^{\circ} \mathrm{T}\right)$, exces-
} 
sive sour-milk flavor and smell. These results don-t allow to provide the long storage term. That is why it is recommended to use the thermal way for proteins extraction from sheep whey and for proteins extraction from cow way in the technology of "Urda" albumin cheese.

So the thermal way of proteins extraction from the mixture of sheep and cow whey in ratio 1:1 or 3:1 can be used for "Urda" albumin cheese production. The use of cow whey gives a possibility to cheapen the product because cow whey is cheaper than sheep one. Such cheese has the improved organoleptic parameters, namely homogenous consistence, tender sour-milk flavor and smell.

Keywords: sheep whey, cow whey, "Urda" albumin cheese, ways of proteins extraction, protein mass.

\section{Introduction}

Cheeses are highly nutritive protein products, received from milk by its clotting and processing [1]. The one of most valuable components of milk whey is whey proteins, which contents reaches $1,5 \%$ [2]. Whey proteins contain all irreplaceable amino acids and their ratio corresponds to the full-value protein that fully provides all life needs of human organism [3, 4]. Albumin milk, albumin sour-milk cheese, albumin mousse, cheese mass "Kavkaz" and so on are produced from whey proteins [5]. But these products did not find the wide spread in Ukraine. At the same time "Urda" cheese of whey proteins that contains all irreplaceable amino acids that in their turn are necessary for the normal functioning of human organism is produced in Carpathian region traditionally from sheep whey $[6,7]$. The necessary stage for albumin "Urda" cheese production is whey proteins extraction from sheep whey. That is why the necessary stage is the study of the ways of proteins extraction from sheep and cow whey and mixtures.

According to the literary data $[8,9]$, the maximal percent of proteins is extracted at the acid-alkaline way. It was established, that whey proteins in the process of extraction by the method of thermal coagulation are subjected to the effect of high temperatures. Their assimilability remains practically identical to the natural ones [10]. That is why the substantiation of the way of proteins extraction from sheep and cow whey for "Urda" cheese production seems to be timely and topical.

\section{Materials and Methods}

The experiments were carried out under conditions of scientific laboratory of the Department of Technology of milk and milk products Lviv National University of Veterinary Medicine and Biotechnologies named after S. Z. Gzhytskyi (Ukraine).

For "Urda" cheese production there were used milk whey from sheep milk and milk whey from cow milk. Sheep and cow whey were chilled to the temperature $(4 \pm 2)^{\circ} \mathrm{C}$ before mixing, reserved up to 4 hours then heated to the temperature $35 \ldots 40{ }^{\circ} \mathrm{C}$. In further the studied whey were separated for cream extraction from skimmed whey. Skimmed whey were pasteurized at the temperature $75 \ldots 80{ }^{\circ} \mathrm{C}$ and chilled to $(4 \pm 2){ }^{\circ} \mathrm{C}$. The chilled sheep and cow whey were mixed in three ratios: $1: 3 ; 1: 1 ; 3: 1$.

Four samples of cheese were prepared with trice repetition:

- control - albumin cheese, prepared of cow whey (Fig. 1);

- variant 1 - albumin cheese, prepared from the mixture of cow and sheep whey in the ratio 1:3;

- variant 2 - albumin cheese, prepared from the mixture of cow and sheep whey in the ratio 1:1;

- variant 3 - albumin cheese, prepared from the mixture of cow and sheep whey in the ratio 3:1 (Fig. 2).

Getting of "Urda" albumin cheese, according to the classic production technology [6], was provided by mixing whey from sheep and cow milk in given proportions and boiling albumin during $30 \mathrm{~min}$ at the temperature $85 . . .90^{\circ} \mathrm{C}$. After sediment formation as protein flakes, the mixtures were chilled to the temperature $(30 \pm 2)^{\circ} \mathrm{C}$. Protein mass was separated and pressed at the temperature $(19 \pm 1)^{\circ} \mathrm{C}$ during $1,5 \ldots 2,0$ hours. Salting of the cheese was carried out at the temperature $(10 \pm 2){ }^{\circ} \mathrm{C}$ then it was packed to non-hermetic package.

The content of general protein in whey and cheese was determined by Kjeldahl method (STST 25179-90) and colorimetric method (SSTC 25179-90). Kjeldahl method is based on the full ashing of the batch of studied product at heating with concentrated sulfuric acid with the cata- 
lyst $(\mathrm{CuO})$. The use of the catalyst favors the rise of the acid boiling temperature. Nitrogen, released at this process, is determined by titration and protein content is calculated by its quantity. The colorimetric method is based on milk whey proteins and cheese ability to bind acid coloring agent at $\mathrm{pH}$ lower than isoelectric point with sediment formation. After its separation there was measured the optic density of the output coloring agent solution relatively to the optimal solution. The density decreases proportionally to the protein mass share.

The titrated acidity of whey and cheese was determined by titrometric method using the phenolphthalein indicator (STST 3624-92).

The mass share of moisture in whey and cheese was determined by drying at the temperature $102 \pm 2{ }^{\circ} \mathrm{C}(\mathrm{STST} 3626-73)$.

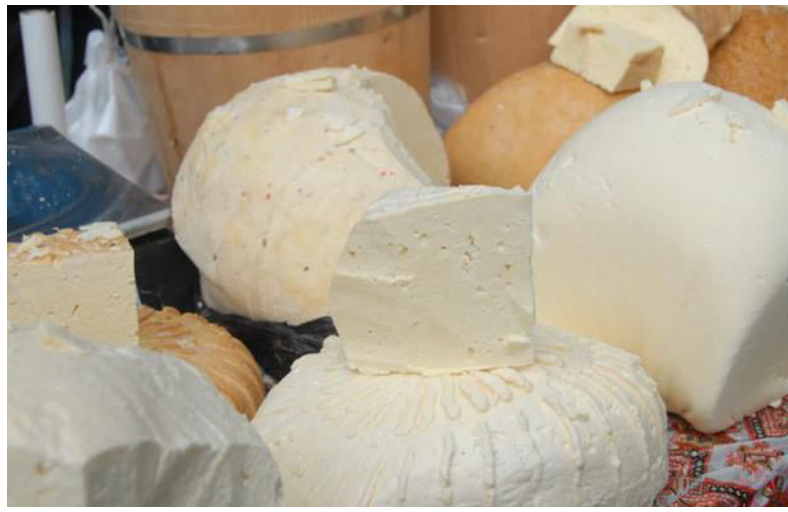

Fig. 1. "Urda" albumin cheese

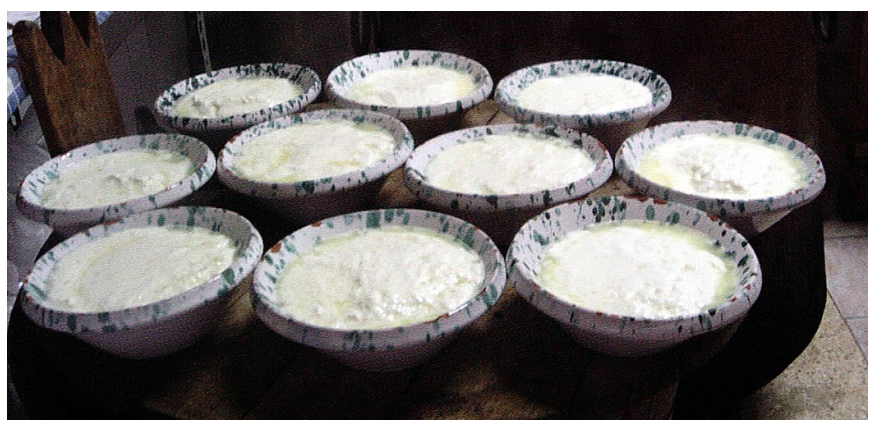

Fig. 2. Experimental variants at proteins extraction by different ways

\section{Results}

It was established, that the most output of protein mass $(3,47 \pm 0,10 \%)$ is at the chlorine-calcium way of proteins extraction, a bit less $-3,41 \pm 0,08 \%$ - at acid-alkaline way (Table 1). But the acidity of such cheese mass, received by the chlorine-calcium and acid-alkaline ways is not high $-37,2 \pm 1,8$ and 45,6 $\pm 1,4 \%$ respectively. Albumin cheese, produced of such protein mass has the insipid, unexpressed flavor.

Albumin cheese, produced of protein mass, received by the acid way has the increased titrated acidity $\left(98 \ldots 104^{\circ} \mathrm{T}\right)$, that conditions the excessive sour-milk flavor in it.

As to the thermal way of proteins extraction, there was registered the least output of protein mass $(3,17 \pm 0,11 \%)$, but albumin cheese, received from such protein mass, was the best by gustatory qualities. The estimation of quality of the received new products was carried out by testing method, at that the standard quality parameters were studied: appearance, consistence, color, flavor and smell of the samples. Each parameter was estimated by 5 -point scale.

The tasting commission marked the high organoleptic parameters of the elaborated products, moreover, the attention was paid just to protein mass, in which proteins were extracted by the thermal way. 
Table 1

Influence of the way of proteins extraction from sheep and cow whey on output and chemical composition of protein mass

\begin{tabular}{|c|c|c|c|c|}
\hline $\begin{array}{c}\text { Way of proteins } \\
\text { extraction }\end{array}$ & $\begin{array}{c}\text { Output of } \\
\text { protein mass, \% }\end{array}$ & $\begin{array}{c}\text { Mass share of protein } \\
\text { in protein mass, \% } \\
\text { Of cow whey }\end{array}$ & $\begin{array}{l}\text { Mass share of moisture } \\
\text { in protein mass, } \%\end{array}$ & $\begin{array}{c}\text { Titrated acidity of } \\
\text { protein mass, }{ }^{\circ} \mathrm{T}\end{array}$ \\
\hline Thermal & $3,17 \pm 0,11$ & $17,5 \pm 0,6$ & $80,0 \pm 0,1$ & $71,3 \pm 0,8$ \\
\hline Acid & $3,32 \pm 0,05$ & $17,3 \pm 0,5$ & $79,7 \pm 0,2$ & $95,8 \pm 1,7$ \\
\hline Acid-alkaline & $3,41 \pm 0,08$ & $17,4 \pm 0,4$ & $79,8 \pm 0,3$ & $45,6 \pm 1,4$ \\
\hline Chlorine-calcium & $3,47 \pm 0,10$ & $17,4 \pm 0,3$ & $80,1 \pm 0,4$ & $37,2 \pm 1,8$ \\
\hline \multicolumn{5}{|c|}{ Of sheep whey } \\
\hline Thermal & $5,31 \pm 0,15$ & $18,8 \pm 1,1$ & $80,4 \pm 0,1$ & $90,0 \pm 2,4$ \\
\hline Acid & $5,50 \pm 0,18$ & $18,5 \pm 1,0$ & $79,8 \pm 0,2$ & $115,5 \pm 1,5$ \\
\hline Acid-alkaline & $5,54 \pm 0,20$ & $18,7 \pm 0,5$ & $79,9 \pm 0,3$ & $57,5 \pm 1,3$ \\
\hline Chlorine-calcium & $5,56 \pm 0,15$ & $18,8 \pm 0,6$ & $80,5 \pm 0,4$ & $48,0 \pm 2,5$ \\
\hline
\end{tabular}

Note: $n=3, P \geq 0,95$

The same dependence of the influence of the way of proteins extraction from sheep whey on the output of protein mass as from cow whey was established: the most output of protein mass $(5,56 \pm 0,15 \%)$ was at the chlorine-calcium way of extraction, a bit less was the acidalkaline $(5,54 \pm 0,20 \%)$ and the acid $(5,50 \pm 0,18 \%)$ ways, the least output was registered at the thermal way $-5,31 \pm 0,15 \%$. It must be noted, that the output of protein mass from sheep whey is $1,60 \ldots 1,67$ higher than from cow whey that is conditioned by the higher content of proteins in sheep whey comparing with cow one.

Protein mass, received from sheep whey by the chlorine-calcium and acid-alkaline ways has lower titrated acidity. Cheese, produced of protein mass, received from sheep whey by the acid method, has extremely high acidity indices $\left(115,5 \pm 1,5^{\circ} \mathrm{T}\right)$ comparing with other methods. That is why it is recommended to use the thermal way for proteins extraction from sheep way and for proteins extraction from cow whey in the technology of "Urda" albumin cheese production.

At the study of thermal coagulation of sheep whey proteins it was established, that the maximal proteins extraction was observed in isoelectric point of albumin fraction of whey proteins at the acidity $37^{\circ} \mathrm{T}$ and $\mathrm{pH} 4,55$. At that the optimal temperature is $95{ }^{\circ} \mathrm{C}$, and duration of keeping - no less $25 \mathrm{~min}$. That is why the thermal coagulation way is recommended in the technology of "Urda" protein cheese production for whey proteins extraction.

For "Urda" cheese production there was recommended to use the mixtures of sheep and cow whey (variants 1...3), so the following stage of experimental studies was determination of the output and chemical composition of protein mass, received by the thermal way from the whey mixtures comparing with the control - sheep whey (Table 2).

The increase of sheep whey mass share in the mixture is associated with increase of protein mass output (most output in the variant $3-4,76 \pm 0,18 \%$ ), that is explained by the highest proteins content in this variant of raw material; in the variant 2 we can also register rather high output of protein mass $-4,25 \pm 0,22 \%$. 
Table 2

Influence of the thermal way of proteins extraction from the mixture of sheep and cow whey on the output and chemical composition of protein mass $(n=3 ; p \geq 95)$

\begin{tabular}{ccccc}
\hline Protein mass & $\begin{array}{c}\text { Output of } \\
\text { protein mass, } \mathbf{\%}\end{array}$ & $\begin{array}{c}\text { Mass share of protein in } \\
\text { protein mass, } \%\end{array}$ & $\begin{array}{c}\text { Mass share of moisture } \\
\text { in protein mass, } \%\end{array}$ & $\begin{array}{c}\text { Titrated acidity of } \\
\text { protein mass, }{ }^{\circ} \mathbf{T}\end{array}$ \\
\hline Control & $5,31 \pm 0,15$ & $18,8 \pm 1,1$ & $80,4 \pm 0,10$ & $90,0 \pm 2,4$ \\
Variant 1 & $3,84 \pm 0,25$ & $17,9 \pm 1,3$ & $79,7 \pm 0,20$ & $83,0 \pm 2,2$ \\
Variant 2 & $4,25 \pm 0,22$ & $18,4 \pm 1,2$ & $80,0 \pm 0,17$ & $85,0 \pm 2,3$ \\
Variant 3 & $4,76 \pm 0,18$ & $18,6 \pm 1,1$ & $80,2 \pm 0,13$ & $87,0 \pm 2,2$
\end{tabular}

The mass share of proteins in protein mass of the variants 2 and $3(18,4 \pm 1,2$ and 18,6 41,1 respectively) is approximated to the one in the control $(18,8 \pm 1,1 \%)$, whereas in the variant 1 this index is by $4,7 \ldots .5,0 \%$ lower comparing with the control.

The moisture content in all studied samples of protein mass was at the fixed level (Table 2), that proves a possibility of "Urda" albumin cheese production of all complex variants of whey mixtures. It must be noted, that the consistence of protein mass in the variant 1 was very easily soiled, not typical for the target product and in the variants 2 and 3 has the acidity 85,0 2,3 and $87,0 \pm 2,2^{\circ} \mathrm{T}$ respectively that allows (in the case of observance of sanitary-hygienic production conditions) to provide the long storage term of the product.

So, the results of the study of influence of the thermal way of proteins extraction from the mixture of sheep and cow whey on the output and chemical composition of protein mass testified that the thermal way of proteins extraction from mixtures of sheep and cow whey in the ratio 1:1 or 3:1 can be used for "Urda" albumin cheese production.

\section{Conclusions}

The influence of the different ways of proteins extraction from cow whey on the output and chemical composition of protein mass was studied. It was established, that the most output of protein mass was at the chlorine-calcium extraction way. Albumin cheese, produced of protein mass, received by the acid way, has the increased titrated acidity $\left(98 \ldots 104^{\circ} \mathrm{T}\right)$. The least output of protein mass was at the use of the thermal way of proteins extraction, but albumin cheese, received from such protein mass, was the best by its flavor qualities.

The influence of the different ways of proteins extraction from sheep whey on the output and chemical composition of protein mass was studied. It was established, that the most output of protein mass was at the chlorine-calcium way of extraction, it was a bit lower at the acid and acid-alkaline ways. The least output of protein mass was registered at the thermal way, it was correspondingly $5,31 \pm 0,15 \%$. Protein mass, received from sheep whey by the chlorine-calcium and acid-alkaline ways has the low titrated acidity. Cheese, produced of protein mass, received from sheep whey by the acid method, has the extremely high acidity values $\left(115,5 \pm 1,5^{\circ} \mathrm{T}\right)$. That is why the thermal way is recommended in the technology of "Urda" protein cheese production for sheep whey proteins extraction.

The influence of the thermal way of proteins extraction from the mixture of sheep and cow whey on the output and chemical composition of protein mass was scientifically grounded. It was established, that the thermal way of proteins extraction from the mixtures of whey in the ratio 1:1 or 3:1 can be used for "Urda" albumin cheese production.

"Urda" cheese production in industrial conditions can occupy the important place in assortment range of milk products, because cheese has the high biological value and flavor qualities. Getting of "Urda" cheese depends on the quantity of fresh sheep milk whey. It is well-known that $450 \ldots 500 \mathrm{~g}$ of "Urda" cheese may be received from $10 \mathrm{dm}^{3}$ of sheep milk, because this product is 
produced of sheep whey only. It is significantly expensive comparing with other types of cheese. But the use of cow milk whey as the additional raw material allows significantly cheapen the cost of ready product. It is also reasonable to use the secondary raw material, created at cheeses production of cow and sheep milk.

\section{References}

[1] Lasik, A., Pikul, J., Dank, R., Cais-Sokolińska, D. (2011). The fermentation dynamics of sheep milk with increased proportion of whey proteins. Acta Scientiarum Polonorum: Technologia Alimentaria, 10 (2), 155-163.

[2] Bilyk, O. Ya., Dronyk, H. V. (2014). Doslidzhennia biolohichnoi tsinnosti albuminovoho syru urda. Kharchova nauka ta tekhnolohiia, 8 (6), 36-40.

[3] Ruska, D., Jonkus, D. (2014). Crude Protein and Non-protein Nitrogen Content in Dairy Cow Milk. Proceedings of the Latvia University of Agriculture, 32 (1), 36-40. doi: 10.2478/plua-2014-0011

[4] El-Hatmi, H. E. H. (2015). Comparison of composition and whey protein fractions of human, camel, donkey, goat and cow milk. Mljekarstvo, 65 (3), 159-167. doi: 10.15567/mljekarstvo.2015.0302

[5] Cisaryk, O., Slyvka, I., Bilyk, O., Lesyk, O. (2013). Sklad ta vlastyvosti ovechogo moloka otrymanogo vid ovec' riznyh porid Bukovyny. Sil's'kyj gospodar, 11-12, 2-5.

[6] Bilyk, O. Ya., Dronyk, H. V. (2014). Developing technologies for producing urda albumin cheese. Eastern-European Journal of Enterprise Technologies, 3 (10 (69)), 49-53. doi:10.15587/1729-4061.2014.25255

[7] Jukalo, A., Storozh, L., Jukalo, V. (2012). Bilky kazei’novogo kompleksu moloka korovy (Bos taurus) jak poperednyky biologichno aktyvnyh peptydiv. Biotehnologija, 5 (4), 21-33.

[8] Ha, M., Sabherwal, M., Duncan, E., Stevens, S., Stockwell, P., McConnell, M. et. al. (2015). InDepth Characterization of Sheep (Ovis aries) Milk Whey Proteome and Comparison with Cow (Bos taurus). PLOS ONE, 10 (10), e0139774. doi: 10.1371/journal.pone.0139774

[9] Fong, B. Y., Norris, C. S., Palmano, K. P. (2008). Fractionation of bovine whey proteins and characterisation by proteomic techniques. International Dairy Journal, 18 (1), 23-46. doi: 10.1016/j.idairyj.2007.06.005

[10] El-Agamy, E. I. (2007). The challenge of cow milk protein allergy. Small Ruminant Research, 68 (1-2), 64-72. doi: 10.1016/j.smallrumres.2006.09.016 